\title{
Review Sinergisitas Kombinasi Polimer Alami Serta Pemanfaatan dalam Formulasi Obat
}

Viviane Annisa ${ }^{1, *}$, Teuku Nanda Saifullah Sulaiman ${ }^{2}$, Akhmad Kharis Nugroho $^{2}$, Agung Endro Nugroho $^{3}$

${ }^{1}$ Fakultas Farmasi, Universitas Gadjah Mada, Yogyakarta, Indonesia

${ }^{2}$ Departemen Farmasetika, Fakultas Farmasi, Universitas Gadjah Mada, Yogyakarta, Indonesia

${ }^{3}$ Departemen Farmakologi dan Klinis, Fakultas Farmasi, Universitas Gadjah Mada, Yogyakarta, Indonesia

*Email: shirvij5@gmail.com

(Submit 30/09/2021, Revisi 15/10/2021, Diterima 08/11/2021, Terbit 10/12/2021)

\begin{abstract}
Abstrak
Pengetahuan tentang sinergisme bermanfaat untuk menentukan kombinasi polimer alami yang memberikan efek menguntungkan ketika dikombinasikan. Interaksi yang saling menguntungkan antar polimer alami dapat dilihat dari nilai sinergisitas dari data pengujian viskositas. Kombinasi polimer yang memiliki efek sinergi dapat memberikan banyak kegunaan serta manfaat yang besar dalam pengembangan teknologi formulasi obat sehingga dapat mengatasi kekurangan yang dimiliki oleh masing-masing zat aktif obat. Pada studi ini, dilakukan review artikel tentang sinergisme kombinasi polimer, pengaruh kation sebagai cross-linker, serta aplikasi kombinasi alginat dengan polimer alami dalam formulasi sediaan obat dan aspek farmakologinya. Database yang digunakan untuk mengambil referensi, meliputi Scopus, PubMed, dan Google Schoolar. Tipe data dari database meliputi jurnal, artikel review, maupun buku tanpa ada pembatasan tahun. Referensi yang diperoleh dari database lalu diidentifikasi, dianalisis, dan dipilih yang sesuai dengan topik yang akan direview. Formulasi dengan polimer menghasilkan obat dengan pelepasan terkontrol, yang memiliki keuntungan, yakni dapat menurunkan frekuensi pemberian dosis, menurunkan efek samping obat, meningkatkan tingkat kepatuhan pasien, menurunkan fluktuasi, serta memperlama durasi aksi obat, dan memastikan respon farmakokinetik dan farmakodinamik dapat reprodusibel dan diprediksi. Selain itu, polimer dapat pula dimodifikasi sedemikian rupa untuk menjadi sistem penghantaran obat tertarget pada organ tertentu. Polimer alami yang paling banyak digunakan dan dikombinasikan dengan polimer lain adalah alginat karena memiliki struktur dengan banyak gugus negatif berupa karboksil dan hidroksil sehingga memiliki berbagai keuntungan, seperti dapat meningkatkan kelarutan obat, meningkatkan kemampuan mukoadesif, melepaskan obat secara terkontrol, serta menghantarkan obat pada target organ tertentu.
\end{abstract}

Kata kunci: Alginat, tautan silang, sinergisitas polimer, formulasi polimer, kombinasi polimer alami 


\section{Pendahuluan}

Interaksi antar kombinasi dua polimer alami cukup menarik untuk dipelajari lebih lanjut sebab beberapa tahun terakhir telah banyak formulasi obat maupun aplikasi pada produksi makanan yang menggunakan kombinasi polimer. Pengetahuan tentang sinergisme dapat bermanfaat untuk mengetahui sifat mekanik dari kombinasi polimer (1). Semakin kuat sifat mekanik kombinasi polimer, maka pelepasan obat dari matriks polimer akan lebih lama dan dapat menurunkan kebocoran sebagai matriks enkapsulasi obat. Kombinasi antar polimer dapat memberikan efek sinergi yang kuat dibandingkan dengan polimer tunggal. Mikrostruktur dari gel yang dihasilkan oleh kombinasi polimer dapat berbeda total dibandingkan dengan gel tunggal (2). Interaksi antar kedua polimer akan menghasilkan perubahan terhadap sifat fisika kimia dari polimer dalam campuran. Salah satu sifat fisika kimia yang dapat mengalami perubahan adalah viskositas. Dari data viskositas, dapat diketahui sinergisitas dalam kombinasi polimer (3). Dikatakan adanya efek sinergi jika sistem dispersi memiliki viskositas lebih tinggi pada kombinasi lebih dari satu hidrokolid polimer dibandingkan dengan hidrokoloid tunggal. Viskositas campuran hidrokoloid dapat meningkat secara non-linear terhadap peningkatan konsentrasi hidrokoloid, sehingga diperlukan mengetahui rasio atau konsentrasi kombinasi yang sesuai ${ }^{(4)}$. Adanya sinergisitas antara kedua campuran polimer juga dapat menurunkan biaya produksi karena jumlah yang dibutuhkan lebih sedikit untuk menghasilkan viskositas yang sama ${ }^{(2)}$. Sinergisme suatu kombinasi polimer dapat ditingkatkan dengan penambahan suatu agen cross-linker. Tautan silang dapat dilakukan secara fisika maupun kimia ${ }^{(5,6)}$. Tautan silang yang menggunakan komponen kimia sebagian besar bersifat toksik dan bereaksi dengan zat aktif yang direaksikan yang menyebabkan zat aktif tersebut menjadi tidak aktif. Maka dari itu, tautan silang lebih disukai menggunakan metode secara fisik. Metode secara fisik dapat dilakukan dengan cara interaksi ionik, self-assembly dari polisakarida hidrofob, kristalisasi polisakarida, induksi ikatan hidrogen antara polisakarida, dan menggunakan molekul protein ${ }^{(7)}$. Penyalutan maupun tautan silang dapat mengubah kecepatan difusi dari molekul yang terenkapsulasi sehingga dapat mengontrol pelepasan molekul.

Kombinasi polimer yang memiliki efek sinergi dapat memberikan banyak manfaat yang besar dalam pengembangan teknologi formulasi obat sehingga dapat mengatasi kekurangan yang dimiliki oleh masing-masing zat aktif obat. Disamping itu, polimer alami lebih disukai dibandingkan dengan polimer sintetik karena bersifat biodegradable, biokompatibel, tidak toksik, memiliki kapabilitas tinggi untuk mengembang, stabil pada berbagai macam $\mathrm{pH}$, lebih ekonomis, serta mudah diperoleh ${ }^{(8)}$. Polimer alami yang paling banyak digunakan dalam aplikasi formulasi obat maupun biomedis adalah alginat. Alginat dapat dengan mudah dimodifikasi secara kimia mapun fisika melalui tautan silang sehingga terbentuk hidrogel dan meningkatkan sifat fisika kimia serta aktivitas biologi ${ }^{(9)}$. 
Kajian tentang polimer alami tunggal terkait kemanfaatannya untuk formulasi obat sudah banyak yang melakukan. Namun, kajian artikel tentang sinergisitas serta penggunaan kombinasi alginat dalam formulasi obat dan aspek farmakologinya, sejauh pencarian penulis, belum ada yang melakukan. Maka dari itu, pada artikel ini, penulis akan mengkaji artikel penelitian yang telah dilakukan mengenai sinergisitas dari kombinasi polimer alami, pengaruh kation sebagai cross-linker, serta aplikasi kombinasi alginat terhadap dengan polimer alami untuk formulasi sediaan obat dan aspek farmakologinya.

\section{Metode}

Beberapa database digunakan untuk mengambil referensi, meliputi database Scopus, PubMed, dan Google Schoolar. Tipe data dari database meliputi jurnal, artikel review, maupun buku tanpa ada pembatasan tahun. Referensi yang diperoleh dari database lalu diidentifikasi, dianalisis, dan dipilih yang sesuai dengan topik yang akan dikaji. Kata kunci yang digunakan, meliputi "Synergy* AND polymer", "Nature* Polymer AND Drug Formula*", "Crosslink* AND Polymer", "Combinat* AND Alginate", "Alginate AND Pectin AND Formulat* AND Drug", "Alginate AND Gum AND Formulat" AND Drug", "Alginate AND Carrageenan AND Formulat" AND Drug", "Alginate AND release AND controlled AND drug AND in vivo AND pharmaco/", "Alginate AND solubility AND bioavailability".

\section{Hasil}

\section{Sinergisme Kombinasi Polimer}

Sinergisme kombinasi polimer mengacu pada adanya asosiasi antar campuran polimer. Campuran gel polimer yang homogen ditentukan dari polimer yang kompatibel dan mampu berasosiasi satu dengan lainnya, dapat diketahui dari sifat fisika kimianya, seperti viskositas dan kekuatan gel ${ }^{(10)}$. Penelitian mengenai sinergisitas kombinasi polimer yang telah dilakukan sebelumnya, sebagian besar menggunakan dari data viskositas. Perubahan viskositas berdasarkan data reologi dari campuran biner dapat menentukan sinergisitas suatu kombinasi polimer. Penurunan viskositas mengindikasikan adanya interaksi asosiatif dengan penurunan volume hidrodinamik dari polimer yang disebabkan oleh asosiasi dari polimer menjadi agregat yang dapat terlarut atau terpresipitasi, sedangkan peningkatan viskositas mengindikasikan interaksi asosiatif dengan interaksi kooperatif intrapolimer dan interpolimer seperti induksi gelasi $(10,11)$. Sinergisitas dapat berupa sinergi negatif (antagonis) yang ditunjukkan adanya penurunan viskositas dan sinergi positif yang ditunjukkan adanya kenaikan viskositas (12). Sinergi positif ditentukan dari pembentukan jaringan, dapat berpasangan dengan atau tanpa adanya pembentukan agregat ${ }^{(10)}$. 
Material biopolimer diketahui tidak memiliki sifat mekanik yang mencukupi sehingga sulit untuk digunakan pada produk spesifik. Untuk mengatasi hal tersebut, dapat dilakukan kombinasi dengan polimer lain maupun dengan logam monovalen ataupun multivalen sebagai cross-linker sehingga dapat meningkatkan efek sinergi dalam kombinasi polimer. Adanya peningkatan sinergisitas ini dapat diketahui dari data viskositas yang diolah ke dalam bentuk persamaan matematika, berupa indeks sinergisme dan persentase deviasi. Penelitian tentang mengetahui sinergisme dalam kombinasi polimer telah banyak dilakukan (Tabel 1).

Analisis sinergisitas antar polimer dapat diketahui dari hasil pengukuran viskositas yang dihitung menggunakan persamaan matematika. Persamaan 1 mendeskripsikan efek sinergistik dari kombinasi polimer, tetapi tidak untuk memprediksi viskositas dari larutan campuran. Persamaan 2 digunakan untuk menghitung power requirements agitasi dari campuran cairan yang tidak bercampur dan untuk memprediksi viskositas rata-rata geometris terhadap nilai viskositas hasil eksperimen ${ }^{(13)}$

$\eta_{\text {mix }}=X_{A} \eta_{A}+X_{B} \eta_{B}$

$\eta_{\operatorname{mix}}=\eta_{A}^{x_{i}} \times \eta_{B}^{x_{B}}$

Keterangan :

$\eta_{\text {mix }}$ : viskositas campuran teoritis

$\eta_{A}$ dan $\eta_{B} \quad$ : viskositas polimer $A$ dan $B$

$X_{A}$ dan $X_{B} \quad$ : fraksi/rasio polimer A dan B

Perbedaan viskositas hasil eksperimen dan perhitungan teoritis dapat dihitung dengan persamaan persentase deviasi (Persamaan 3). Hasil perhitungan dari \% deviasi dapat menentukan sinergisitas dari kombinasi polimer. Hasil negatif mengindikasikan terdapat efek antagonis, sedangkan nilai positif mengindikasikan terdapat efek sinergi ${ }^{(10)}$. Nilai 0 menunjukkan tidak terdapat interaksi ${ }^{(12)}$.

$\%$ deviation $=\left(\frac{\eta_{\text {exp }}}{\eta_{\text {theori }}}-1\right) \times 100 \%$

Keterangan :

$\eta_{\text {exp }} \quad$ : viskositas eksperimen

$\eta_{\text {theori }}$ : viskositas teoritis

Indeks viskositas dapat dihitung menggunakan persamaan 4. Jika nilai indeks viskositas lebih dari 0,5 maka dapat dikatakan terdapat efek sinergisme dalam kombinsi polimer ${ }^{(11)}$.

Synergism index $=\frac{\eta_{\text {mix }}}{\eta_{A}+\eta_{B}}(4)$ 
Table 1. Sinergisme Kombinasi Polimer

\begin{tabular}{|c|c|c|c|}
\hline No & Jenis Polimer & Hasil & Referensi \\
\hline 1 & $\begin{array}{l}\text { Alginat, gum dari batang Triumfetta } \\
\text { cordifolia and Bridelia thermifolia, } \\
\text { biji dari Irvingia gabonensis dan } \\
\text { Beilschmiedia obscura, dan daun } \\
\text { dari Ceratotheca sesamoides, } \\
\text { Adansonia digitata dan Corchorus } \\
\text { olitorius }\end{array}$ & $\begin{array}{l}\text { Di dalam larutan air, campuran } \\
\text { antar alginat dan gum dari T. } \\
\text { cordifolia, B. obscura, C. } \\
\text { sesamoides and C. olitorius saling } \\
\text { sinergis. Dalam larutan } \mathrm{CaCl}_{2} \text {, } \\
\text { campuran alginat dan ketujuh gum } \\
\text { alami menghasilkan interaksi } \\
\text { sinergis }\end{array}$ & $(10)$ \\
\hline 2 & $\begin{array}{l}\text { Gum vinal, gum xanthan, } \\
\text { karagenan, natrium alginat }\end{array}$ & $\begin{array}{l}\text { Gum vinal dan gum xanthan } \\
\text { menghasilkan efek yang sinergis. } \\
\text { Gum vinal tidak memperlihatkan } \\
\text { sinergisme dengan k-karagenan } \\
\text { atau natrium alginat }\end{array}$ & (14) \\
\hline 3 & Gum ghatti dan natrium alginat & $\begin{array}{l}\text { Terdapat interaksi sinergi yang kuat } \\
\text { antara natrium alginat dan gum } \\
\text { ghatti }\end{array}$ & (3) \\
\hline 4 & Gum guar dan alginat & $\begin{array}{l}\text { Terdapat interaksi sinergi antara } \\
\text { gum guar dan natrium alginat }\end{array}$ & (15) \\
\hline 5 & $\begin{array}{l}\text { Kacang kedelai/minyal zaitun } \\
\text { dengan } 3 \text { gum (gum xanthan, } \\
\text { natrium alginat, gum locust bean) }\end{array}$ & $\begin{array}{l}\text { Terdapat interaksi sinergi dari } \\
\text { kombinasi gum xanthan dan locust } \\
\text { bean yang dilihat dari nilai index } \\
\text { viscous synergy }\end{array}$ & (16) \\
\hline 6 & $\begin{array}{l}\text { Gum Gleditsia triacanthos (Gt), gum } \\
\text { xanthan, karagenan, Carboxymethyl } \\
\text { cellulose (CMC), dan alginat }\end{array}$ & $\begin{array}{l}\text { Sinergisme yang paling bagus } \\
\text { terdapat pada gum Gt dengan gum } \\
\text { xanthan dibandingkan dengan } \\
\text { polimer lainnnya }\end{array}$ & (4) \\
\hline 7 & $\begin{array}{l}\text { Gum konjac, gum xanthan, gum } \\
\text { guar, karangenan, natrium alginat, } \\
\text { CMC, Hidroxypropyl Methyl } \\
\text { cellulose (HPMC), gum akasia }\end{array}$ & $\begin{array}{l}\text { Interaksi gum konjac yang paling } \\
\text { kuat adalah dengan gum xanthan. } \\
\text { Kekuatan interaksi gum konjac } \\
\text { dengan polisakarida lainnya, } \\
\text { berturut-turut mulai yang paling } \\
\text { kuat sampai paling lemah: non-ionik } \\
\text { (gum guar) > ionik (karagenan, } \\
\text { natrium alginat, dan CMC) > } \\
\text { hidrofobik (HPMC) > hidrofobik } \\
\text { teremulsi (gum akasia) }\end{array}$ & (17) \\
\hline 8 & $\begin{array}{l}\text { K-karagenan, gum locust bean, } \\
\text { gum guar, gum xanthan, } \\
\text { i-karagenan, Na-CMC, dan natrium } \\
\text { alginat }\end{array}$ & $\begin{array}{l}\text { Campuran k-karagenan dengan } \\
\text { gum locust bean memperlihatkan } \\
\text { efek sinergi. Campuran } \\
\text { k-karagenan dengan natrium } \\
\text { alginat memperlihatkan interaksi } \\
\text { sinergis yang kuat secara termal, } \\
\text { tetapi tidak ada efek partikular yang } \\
\text { terinduksi pada sifat fungsional }\end{array}$ & (18) \\
\hline
\end{tabular}




\begin{tabular}{|c|c|c|c|}
\hline$\overline{9}$ & Kalsium alginat dan karagenan & $\begin{array}{l}\text { Kombinasi kalsium alginat dan } \\
\text { karagenan memiliki interaksi yang } \\
\text { sinergi sehingga dapat } \\
\text { meningkatkan kekuatan mekanik }\end{array}$ & 9) \\
\hline 10 & $\begin{array}{l}\text { K-karagenan, gum akasia, gum } \\
\text { locust bean, gum guar, gum konjac, } \\
\text { gum xanthan, alginat, CMC, HPMC, } \\
\text { i-karagenan, dan agar }\end{array}$ & $\begin{array}{l}\text { K-karagenan memiliki efek sinergi } \\
\text { yang baik dengan gum akasia, gum } \\
\text { locust bean, gum konjac, dan } \\
\text { HMPC, sedangkan efek antagonis } \\
\text { terjadi pada gum xanthan, alginat, } \\
\text { CMC, dan agar }\end{array}$ & (11) \\
\hline 11 & Alginat dan pektin & $\begin{array}{l}\text { Kombinasi alginat dan pektin } \\
\text { memiliki interaksi yang sinergi }\end{array}$ & (20) \\
\hline 12 & Alginat dan pektin & $\begin{array}{l}\text { Alginat dan pektin memiliki efek } \\
\text { sinergis untuk meningkatkan sifat } \\
\text { mekanik microbeads dari kombinasi } \\
\text { polimer tersebut }\end{array}$ & (21) \\
\hline 13 & Alginat dan pektin & $\begin{array}{l}\text { Interaksi sinergi yang paling kuat } \\
\text { antara alginat dan pektin terdapat } \\
\text { pada rasio } M / G \text { alginat yang rendah } \\
\text { dan derajat esterifikasi pektin yang } \\
\text { tinggi }\end{array}$ & (2) \\
\hline 14 & Alginat dan gum xanthan & $\begin{array}{l}\text { Koefisien viskositas dari dispersi } \\
\text { komposit lebih rendah dari dispersi } \\
\text { gum xanthan. Hal ini } \\
\text { mengindikasikan terdapat efek } \\
\text { sinergisme antara alginat dan gum } \\
\text { xanthan }\end{array}$ & (22) \\
\hline 15 & Gum xanthan dan gum locust bean & $\begin{array}{l}\text { Terdapat intermolekular sinergisme } \\
\text { antara gum xanthan dan gum locust } \\
\text { bean pada rasio } 60 \%: 40 \%\end{array}$ & (23) \\
\hline 16 & $\begin{array}{l}\text { Hidrokoloid gum C. olitorius, gum } \\
\text { locust bean, dan karagenan }\end{array}$ & $\begin{array}{l}\text { Hidrokoloid gum C. olitorius } \\
\text { memiliki sinergi yang kuat terhadap } \\
\text { karagenan sehingga dapat } \\
\text { dijadikan alternatif pengganti gum } \\
\text { locust bean }\end{array}$ & (24) \\
\hline
\end{tabular}


Ekstrak gum yang berasal dari spesies vegeta tropikal meliputi Triumfetta cordifolia, Bridelia thermifolia, Irvingia gabonensis, Beilschmiedia obscura, Ceratotheca sesamoides, Corchorus olitorius dan Adansonia digitata telah diteliti sinergisitasnya terhadap alginat ${ }^{(10)}$. Di dalam larutan $\mathrm{CaCl}_{2}$, seluruh gum berinteraksi dengan alginat. Namun, di dalam air, tidak semua gum menunjukkan interaksi yang sinergi. Sinergisitas ini dilihat dari nilai deviasi viskositas, sinergi negatif menunjukkan adanya asosiasi yang kemudian memicu terbentuknya agregat, sedangkan sinergi positif menunjukkan terdapat interaksi kooperatif yang dominan sehingga terbentuk jaringan berpasangan, hal ini dapat diindikasikan dari gel campuran yang potensial pada konsentrasi lebih tinggi ${ }^{(10)}$.

Tambahan $\mathrm{CaCl}_{2} 2 \mathrm{mM}$ memperlihatkan adanya interaksi sinergi yang positif dengan alginat. Hal ini dapat dilihat dari peningkatan viskositas yang mengindikasikan adanya interaksi koperatif antara polimer. Gum dan alginat sama-sama bermuatan negatif sehingga dapat berinteraksi dengan kation divalen dari logam $\mathrm{Ca}^{2+}$ dari larutan garam $\mathrm{CaCl}_{2}$ lalu dapat menurunkan repulsi elektrostatik. Gum yang bermuatan rendah seperti $B$. obscura, memiliki interaksi yang lebih tinggi di dalam air dibandingkan dengan di dalam $\mathrm{CaCl}_{2}$ sebab jumlah ikatan hidrogen yang terbatas. Namun, pada gum lain bermuatan lebih tinggi, interaksi permukaan yang dihasilkan lebih rendah. Berdasarkan hal tersebut, maka dapat disimpulkan bahwa keberadaan muatan dari gugus karboksil dapat berperan terhadap sinergisitas dengan alginat, tetapi ketika melewati batas, maka dapat menyebabkan terjadinya repulsi ${ }^{(10)}$.

Kombinasi alginat dan gum akasia yang bertautan silang dengan kalsium dapat menghasilkan hidrogel. Kombinasi alginat dan gum akasia berinteraksi menggunakan teknik gelasi ionotropik melalui reaksi tautan silang antara gugus hidroksi dari kedua polimer (25). Penambahan gum akasia ke dalam larutan alginat dapat mereduksi side-by-side agregasi dari struktur egg-box alginat akibat adanya ion $\mathrm{Ca}^{2+}$. Side-by-side agregasi ini memicu terjadinya kehilangan kapasitas swelling dari kalsium alginat. Gum akasia merupakan polimer amfolitik sehingga gum akasia dapat menarik molekul alginat melalui gaya elektrostatik ${ }^{(26)}$. Ion $\mathrm{Ca}^{2+}$ berinteraksi dengan residu glukoronat alginat serta gugus hidroksil dari alginat dan gum karena kaya elektron sehingga disukai oleh kation dari ion $\mathrm{Ca}^{2+}$. Kombinasi tersebut menghasilkan sifat mekanik dari network polymer untuk membentuk suatu hidrogel yang lebih kuat. Ion $\mathrm{Ca}^{2+}$ berikatan dengan gugus negatif dari polimer sehingga muatan negatifnya menurun ${ }^{(27)}$. 
Ikatan antara pektin dan alginat terbentuk pada region metil ester dari pektin dan gugus asam guluronat $(G)$ dari alginat ${ }^{(2)}$. Ikatan antar alginat dan pektin dapat menstabilkan komposit yang dihasilkan. Ikatan ini berasal dari gugus guluronat-guluronat (G-G) dan manuronat-guluronat (M-G) dari alginat terhadap gugus galakturonat dari pektin. Menurut Walkenstrom, et al (2003), mikrostruktur dari pektin tunggal memperlihatkan bahwa jaringan pektin memiliki ukuran pori yang lebih kecil dibandingkan dengan kombinasi jaringan ${ }^{(2)}$. Ion $\mathrm{Ca}^{2+}$ berinteraksi dengan gugus karboksil dari alginat dan pektin, kemudian membentuk tautan silang antara rantai polimer yang terpisah dan mengurangi repulsi elektrostatik antara polimer. Dalam pembentukan egg-box dari kombinasi alginat dan pektin, daya dorong utamanya adalah interaksi elektrostatik, selain itu ada pula interaksi lainnya yang berkontribusi, seperti ikatan hidrogen, Van der Waals, serta interaksi hidrofobik ${ }^{(28)}$. Pengaruh $\mathrm{pH}$ sangat krusial terhadap karakter dari gel alginat/pektin yang terbentuk. Kekuatan gel akan meningkat seiring dengan penurunan $\mathrm{pH}$ dari 3.5 menjadi $3.0^{(2)}$. Telah banyak studi telah dilakukan untuk menginvestigasi hubungan sinergi antara alginat dan berbagai tipe pektin (metoksi rendah, metoksi tinggi, dan pektin teramidasi). Efek sinergisme yang dihasilkan berasal dari interaksi molekular antara $\alpha-D$-asam galakturonat pada pektin dengan $\alpha-D$-asam guluronat pada alginat ${ }^{(20)}$.

Koefisien viskositas dari dispersi alginat mengalami peningkatan yang signifikan seiring dengan kenaikan jumlah gum xanthan. Hal ini mengindikasikan adanya sinergisme antara alginat dan gum xanthan. Meskipun demikian, struktur gel dari gum xanthan rusak ketika berikatan dengan alginat. Hal ini menyebabkan kehilangan jaringan kompleks gum xanthan sehingga viskositas gum xanthan menurun. Namun, gum xanthan masih dapat membentuk agregasi kecil yang dapat dilihat secara visual. Agregasi ini dapat membentuk ikatan intermolekular, seperti ikatan hidrogen dari gugus karboksil, hidroksil, dan eter pada alginat dan dari gugus hidroksil dan karboksil pada xanthan. Kemudian menyebabkan viskositas kedua campuran dispersi meningkat ${ }^{(22,29)}$. Kombinasi alginat dan karagenan dapat membentuk hidrogel dengan ion kalsium melalui gugus karboksil dari alginat dan gugus sulfat maupun karboksil dari karagenan (30). Penambahan garam seperti $\mathrm{CaCl}_{2}$ dengan konsentrasi yang sesuai dapat meningkatkan kekuatan gel atau modulus elastis dari gel karagenan dari meningkatnya susunan konformasi coil-to-helix dan selanjutnya teragregasi. Jaringan gel sangat tergantung dengan konsentrasi dan jenis garam yang ditambahkan. Mekanisme pengaruh dari konsentrasi garam terhadap kekuatan gel masih belum jelas terhadap efek non-spesifik kontribusi electrostatic shielding, efek ikatan ion berpasangan, dan hidrasi kation. Kation mendorong gelasi karagenan yang dapat menstabilisasi konformasi heliks dari karagenan dengan shielding muatan dari gugus sulfat, lalu diikuti dengan koordinasi intermolekular (ion-dipol) yang berikatan dengan polisakarida menjadi agregat ${ }^{(31)}$. 
Gum Locust Bean (GLB) merupakan galaktoman yang tidak dapat membentuk gel dengan sendirinya. Hidrokoloid Corchorus olitorius (HC) merupakan tanaman alami yang menghasilkan hidrokoloid dari daun. HC yang dapat berinteraksi dengan kappa-karagenan. Sifat reologi dari campuran gel karagenan dengan HC atau GLB dapat diukur dari kekuatan gel. Penambahan $\mathrm{HC}$ ke dalam dispersi karagenan dapat menghasilkan kekuatan gel yang lebih tinggi dibandingkan dengan gel tanpa HC. Kekuatan gel tertinggi diperoleh pada perbandingan 90:10 (HC:karagenanan). Untuk sinergi karagenan dan GLB diperoleh kekuatan gel yang lebih tinggi 2x dibandingkan dengan campuran karagenan dan HC. Penambahan GLB ke dalam karagenan dapat meningkatkan jaringan berpasangan dengan jembatan spesifik, kemudian dapat memperbaiki reologi dari campuran gel ${ }^{(24)}$.

Kekuatan gel karagenan meningkat dengan adanya penambahan kalsium. Gelasi karagenan merupakan kompleks dan transisi rantai helix yang diikuti oleh agregasi dan pembentukan jaringan. Namun, ketika ditambahkan pada campuran karagenan dan $\mathrm{HC}$, terjadi penurunan kekuatan gel sehingga mengindikasikan bahwa pengaruh kation terhadap kekuatan gel adalah kecil ${ }^{(24)}$.

Gum xanthan dikenal memiliki interaksi sinergi yang kuat dengan galaktomanan, seperti GLB dan gum guar. Interaksi ini melalui ikatan intermolekular antara xanthan dan galaktomanan dari eksklusi mutual dari molekul inkompatibel ${ }^{(23,32)}$. Studi mengenai interaksi antara xanthan dan GLB telah dilakukan oleh Tako (1984) menggunakan sifat reologi. Hasilnya memperlihatkan bahwa interaksi yang terjadi antara rantai samping xanthan yang dapat berikatan dengan lebih dari 1 rantai GLB memiliki model seperti lock and key ${ }^{(33)}$. Sinergisme campuran gum yang lebih tinggi ditemukan pada kombinasi xanthan $60 \%$ dan GLB $40 \%$ dengan dibuktikan dari nilai komponen elastik yang mencapai 2-3 kali lebih besar dibandingkan rata-rata kedua gum. Hal ini juga sejalan dengan data viskositas ${ }^{(23)}$.

\section{Ion Logam Sebagai Cross-Linker}

Tautan silang dapat dilakukan secara fisika maupun kimia. Tautan silang secara fisik dapat berupa ikatan non-kovalen seperti ikatan hidrogen dan Van der Waals, interaksi hidrofobik, maupun lilitan antar polimer. Tautan silang secara kimia melalui ikatan kovalen antara rantai polimer dengan cross-linker seperti glutaradelhid, silikat, epoksi, dII ${ }^{(5,6)}$. Metode secara kimia melalui 2 pendekatan, yaitu tautan silang polifungsional material dari monomer hidrofilik atau melalui polimerisasi 3 dimensi. Tautan silang yang menggunakan komponen kimia sebagian besar bersifat toksik dan bereaksi dengan zat aktif yang direaksikan yang menyebabkan zat aktif tersebut menjadi tidak aktif. Maka dari itu, tautan silang lebih disukai menggunakan metode secara fisik. Metode secara fisik dapat dilakukan dengan cara interaksi ionik, self-assembly dari polisakarida hidrofob, kristalisasi polisakarida, induksi ikatan hidrogen antara polisakarida, dan menggunakan molekul protein ${ }^{(7)}$. 
Logam multivalen dapat berperan sebagai cross-linker untuk polimer bermuatan negatif. Adanya penambahan kation akan mempengaruhi hasil pembentukan gel dari kombinasi polimer karena sifat fisika kimianya dapat berubah. Perubahan yang dihasilkan, antara lain: perubahan jaringan struktur yang terbentuk, sifat reologi, atau hidrofobisitas. Kation bervalensi seperti kalsium dari garam $\mathrm{CaCl}_{2}$ dapat berinteraksi dengan gugus negatif dari polimer, seperti gugus hidroksil, karboksil, amino, dan gugus sulfat melalui ikatan hidrogen. Kation divalen dilaporkan dapat menambah kekuatan pembentukan obat ${ }^{(34)}$.

Terdapat dua metode untuk preparasi penambahan $\mathrm{Ca}^{2+}$ sebagai cross-linker, yakni secara eksternal Nan intamnal innmhar 11
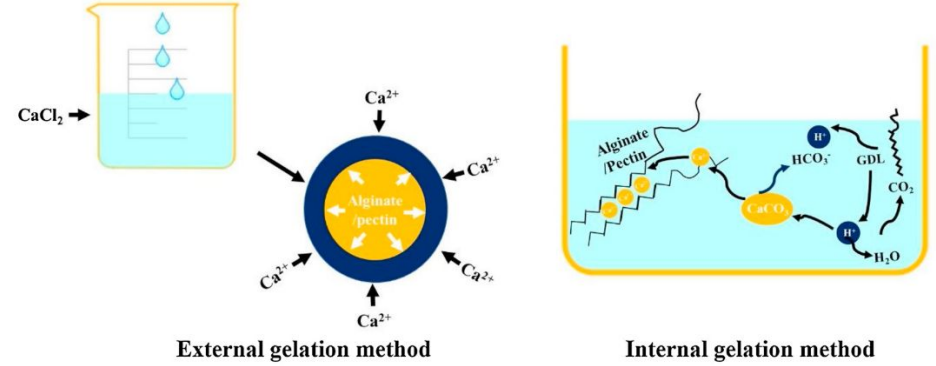

Gambar 1 Teknik gelasi alginat dengan garam kalsium ${ }^{(28)}$

Perbedaan kedua metode terletak pada cara pencampuran dengan garam kalsium serta kinetika gelnya. Metode gelasi eksternal dikenal sebagai metode pengaturan difusi, dimana ion kalsium dapat secara bebas berdifusi ke dalam droplet polimer. Metode ini dilakukan dengan cara meneteskan larutan alginat yang telah berisi obat ke dalam larutan yang mengandung garam kalsium, seperti $\mathrm{CaCl}_{2}{ }^{(35)}$. Kation berdifusi dari daerah konsentrasi lebih tinggi ke dalam interior partikel alginat. Gel yang dipreparasi melalui metode gelasi eksternal memiliki struktur yang tidak homogen karena konsentrasi kalsium cenderung lebih tinggi di permukaan daripada tengah. Pada lapisan terluar hidrogel-kation, kinetik gel bergerak dengan cepat dan formasi gel terjadi secara instan ${ }^{(28,36)}$. Metode gelasi internal dikenal sebagai "internal setting" yang dikarakterisasi dengan perilisan ion kalsium dalam pelepasan terkontrol dari sumber kalsium yang tidak larut, seperti kalsium karbonat dalam larutan alginat. Pelepasan ion kalsium ke dalam larutan polimer secara terkontrol biasanya ditentukan oleh perubahan $\mathrm{pH}$, keterbatasan kelarutan dari sumber garam kalsium, atau keberadaan agen pengkhelat ${ }^{(35)}$. Gel yang dipreparasi melalui metode gelasi internal memperlihatkan struktur gel yang homogen. Namun, memiliki kekurangan, yaitu struktur gel yang dihasilkan lebih longgar dan kekuatannya lebih rendah dibandingkan dengan metode gelasi eksternal ${ }^{(28,36)}$. 
Gum memiliki muatan negatif, ketika ditambahkan garam seperti $\mathrm{CaCl}_{2}$, maka terjadi perubahan konformasi dan viskositas intrinsik, yakni viskositas intrinsiknya lebih kecil dibandingkan dalam air. Hal ini disebabkan karena ion kalsium dalam larutan menurunkan repulsi dan membiarkan gum mengadopsi konformasi fungsionalnya yang sebenarnya. Sebaliknya, di dalam air terjadi mutual repulsi yang mengakibatkan gum terdorong untuk ekspansi dan mengadopsi beberapa konformasi rigid sehingga gyration radius lebih tinggi kemudian terjadi peningkatan viskositas intrinsik. Gum lebih larut dalam larutan $\mathrm{CaCl}_{2}$ (selain $B$. obscura), hal ini menunjukkan bahwa rantai polimer dari gugus karboksil pada residu uronil gum dapat berinteraksi dengan ion. Peningkatan konsentrasi garam yang mengandung kation divalen pada awalnya akan menghasilkan kontraksi gum sehingga viskositasnya menurun ${ }^{(10)}$.

Adanya kation bervalensi seperti kalsium dapat meningkatkan viskositas larutan alginat (37). Penambahan ion kalsium ke dalam polimer alginat menyebabkan terbentuknya ikatan antara 2 rantai $G$ pada sisi yang berlawanan. Ikatan ion kalsium oleh multi-koordinasi dengan gugus oksigen dan karboksil. Konfigurasi ikatan polimer yang kuat menghasilkan formasi junction zone seperti bentuk "egg-box" (Gambar 2).

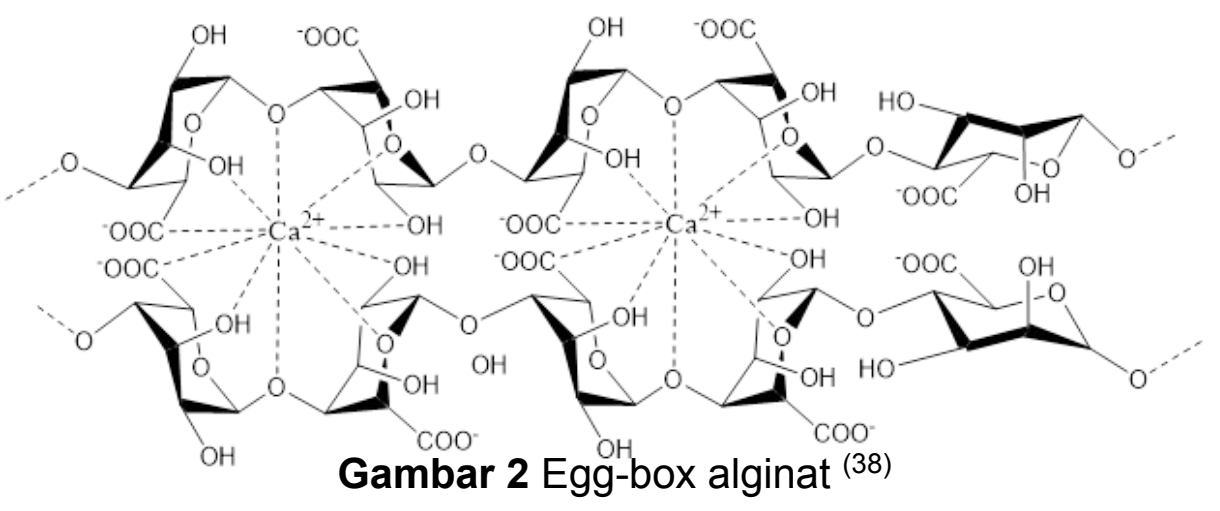

Setiap ikatan kation dengan 4 residu G dalam formasi "egg-box" membentuk jaringan 3-D dari region interkoneksi tersebut ${ }^{(36)}$. Alginat dapat membentuk ikatan hidrogen dengan polimer lain melalui interaksi molekuler dari gugus karboksil, hidroksil, dan eter (10). Pada sistem tautan silang alginat dengan $\mathrm{CaCl}_{2}$, gradien tekanan osmosis antara gel alginat dan lingkungan merupakan faktor penting dalam proses swelling. Pada $\mathrm{pH}$ rendah atau kondisi lambung, pelepasan makromolekul dari alginat secara signifikan menurun dan tidak terjadi swelling. Ketika alginat masuk ke dalam usus (suasana basa atau netral), lapisan asam alginat dikonversikan ke dalam lapisan kental terlarut sehingga akan mengalami swelling, dimana pelepasan obat tergantung pada proses swelling dan erosi ${ }^{(39,40)}$. Tautan silang alginat dapat juga terjadi secara gelasi asam ketika $\mathrm{pH}$ larutan dibawah pKa polimer atau dibawah 3. Gelasi asam alginat distabilkan oleh ikatan hidrogen dan residu M. Kekuatan gel berkorelasi dengan komposisi residu $\mathrm{G}$ dalam rantai polimer ${ }^{(36)}$. Jika dibandingkan dengan gelasi ionik, gelasi ionik dapat membentuk jaringan 3 dimensi yang lebih kuat dibandingkan dengan gelasi asam ${ }^{(7)}$.

Pektin dapat membentuk struktur "egg-box" dengan adanya ion $\mathrm{Ca}^{2+}$ seperti halnya dengan alginat. Pembentukan "egg box" dari pektin melalui gugus $-\mathrm{COOH}$ dengan ion $\mathrm{Ca}^{2+}$ (Gambar 3). 


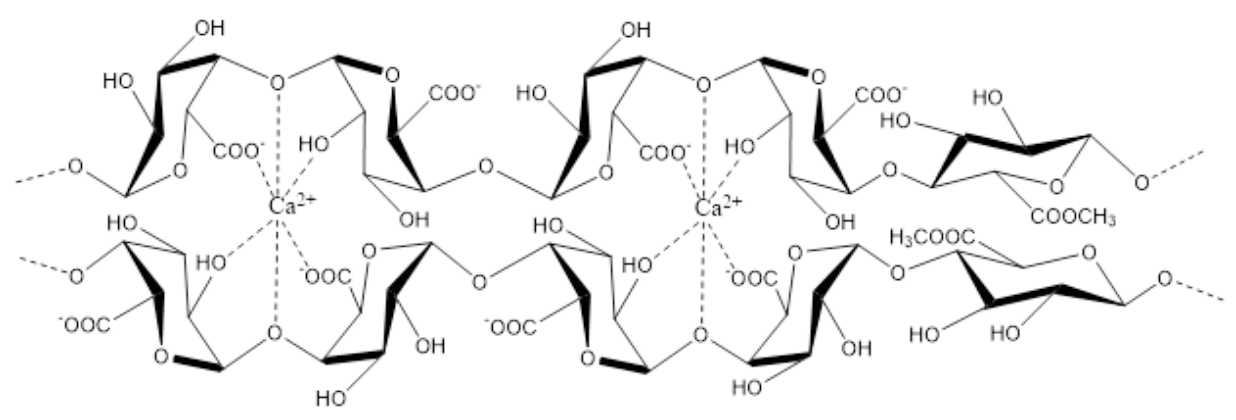

Gambar 3 Egg-box Pektin (41)

Rantai pektin terdiri dari gugus yang teresterifikasi dengan gugus metil dan gugus asam bebas yang dapat berikatan degan ion logam atau ammonium. Pektin tergolong menjadi 2 kelompok berdasarkan derajat esterifikasi (DE), yakni DE tinggi atau high methoxyl (HM) dengan nilai DE sebesar $60-75 \%$ dan DE rendah atau low methoxyl (LM) dengan nilai DE $20-40 \%{ }^{(41)}$. Pembentukan gel pada pektin dengan ion $\mathrm{Ca}^{2+}$ lebih disukai jika pektin memiliki DE rendah dibandingkan dengan DE tinggi. Semakin rendah derajat esterifikasi, maka semakin banyak gugus karboksilat yang tidak termetilasi sehingga dapat lebih banyak berikatan dengan $\mathrm{Ca}^{2+}{ }^{28)}$. DE tinggi tidak mengandung cukup gugus asam untuk membentuk gel atau presipitat terhadap ion $\mathrm{Ca}^{2+}$. Ikatan hidrogen dan interaksi hidrofobik merupakan faktor penting terjadinya agregasi dari molekul pektin. Pembentukan gel dapat terjadi karena adanya ikatan hidrogen antara gugus karboksil bebas dan gugus hidroksil dari molekul lain ${ }^{(41)}$. Meskipun demikan, distribusi gugus metil pada rantai pektin tidak diketahui, sehingga sulit untuk mengetahui pengaruh dari perbedaan dalam struktur blok terhadap peningkatan kekuatan gel. Aksi region pektin teramidasi dalam sistem dapat menyebabkan reduksi dalam repulsi elektrostatik, hal ini sama seperti region yang termetilasi (2).

Karagenan dapat mengalami gelasi ionik dengan ion monovalen maupun ion divalen, seperti ion $\mathrm{K}^{+}$atau $\mathrm{Ca}^{2+}$. Interaksi karagenan dengan ion $\mathrm{Ca}^{2+}$ terjadi melalui tarikan elektrostatik yang kemudian membentuk jembatan intramolekular antara oksigen dari endoeter dan gugus $\mathrm{OSO}_{3}{ }^{-}$dari karagenan. Lalu selanjutnya terbentuk suatu jaringan tautan silang antar makromolekul karagenan. Kation dapat menginduksi konformasi dalam polimer melalui transisi coil-helix lalu terjadi agregasi dari helix untuk membentuk gel ${ }^{(42)}$. Fase separasi dapat terjadi tergantung pada kandungan ester sulfat dari karagenan. Semakin sedikit gugus sulfat, maka kemungkinan terjadinya fase separasi akan lebih lambat ${ }^{(43)}$. Terdapat 3 tipe karagenan yang dibedakan berdasarkan jumlah dari gugus sulfat, yaitu iota (i), kappa (k), dan gamma $(\lambda)$.

lota karagenan merupakan karagenan yang memiliki jumlah gugus sulfat terbanyak dari polisakarida helix-forming dibandingkan dengan jenis karagenan lainnya, sehingga berat molekulnya juga tinggi. Interaksi iota karagenan lebih efektif dengan ion divalen seperti $\mathrm{Ca}^{2+}$ dibandingkan dengan kation monovalen. Jembatan intramolekular terbentuk dari ion $\mathrm{Ca}^{2+}$ yang berada diantara gugus sulfat dari residu anhydro-D-galaktosa dan D-galaktosa yang berdekatan (Gambar 4). Meskipun demikian, kation monovalen juga dapat membentuk jembatan intramolekular, namun tidak sama kuatnya dengan kation divalen karena hanya terbentuk struktur rod-like tunggal, tidak dapat membentuk double helix ${ }^{(44)}$. 


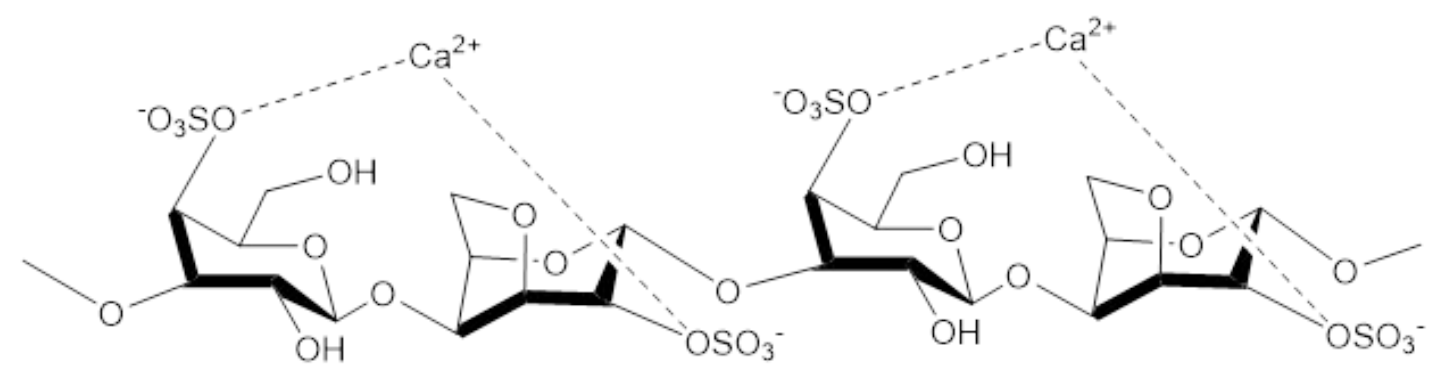

Gambar 4 Interaksi iota karagenan dengan kation monovalen ${ }^{(45)}$

Kappa karagenan memiliki sifat fungsional fisik yang baik maupun memiliki aktivitas biologi sehingga banyak digunakan pada industri makanan, kosmetik, tekstil, maupun farmasi ${ }^{(46)}$. Kappa karagenan memiliki 1 muatan negatif dari gugus sulfat yang memiliki kemampuan membentuk gel dan pembentukan film yang baik serta memiliki kekuatan tensil tertinggi diantara tipe karagenan lainnya ${ }^{(47)}$. Kappa karagenan dapat berikatan dengan kation monovalen (Gambar 5) dan kation divalen (Gambar 6). Gelasi kappa karagenan umumnya dapat dicapai dalam 2 tahapan, yakni transisi coil-helix yang diikuti dengan agregasi helices. Proses ini berdasarkan keberadaan double helix dalam zona penghubung dari jaringan gel karagenan. Kappa karagenan merupakan poli-ion dan sangat sensitif terhadap keberadaan garam karena kation mempengaruhi transisi coil-helix dan agregrasi dari helices. Kation monovalen dapat berikatan dengan helices lalu akan memicu agregasi dari helices, selanjutnya akan menurunkan densitas muatan dari helices ${ }^{(31)}$.

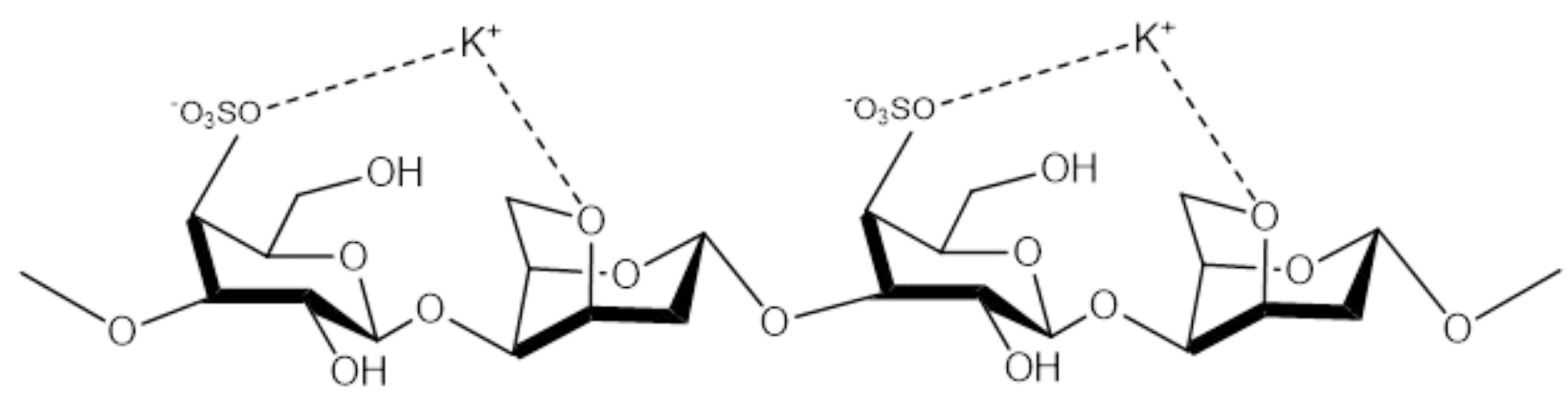

Gambar 5 Interaksi kappa karagenan dengan kation monovalen ${ }^{(45)}$

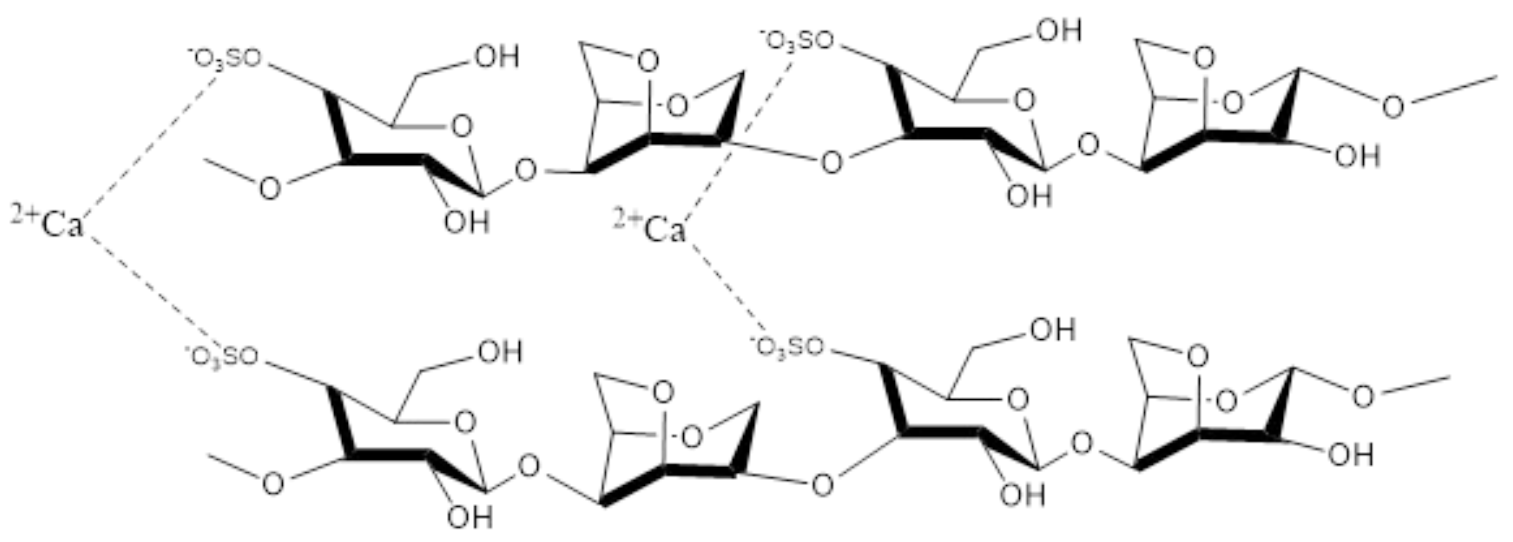

Gambar 6 Interaksi kappa karagenan dengan kation divalen ${ }^{(45)}$ 
Penambahan garam seperti $\mathrm{NaCl}, \mathrm{KCl}$, dan $\mathrm{CaCl}_{2}$ pada konsentrasi yang sesuai dapat meningkatkan kekuatan gel atau modulus elastis, lalu dapat meningkatkan penyusunan konformasi dan agregasi sub-sekuen. Efektivitas pengaruh logam terhadap peningkatan sifat alir dapat diurutkan untuk kation monovalen, yakni $\mathrm{Rb}^{+}>\mathrm{Cs}^{+}>\mathrm{K}^{+}>$ $\mathrm{Na}^{+}>\mathrm{Li}^{+}{ }^{(48)}$. Logam dari ion $\mathrm{Rb}^{+}, \mathrm{Cs}^{+}$, dan $\mathrm{K}^{+}$lebih efektif sebab cenderung sebagai ion structural disordering, sedangkan $\mathrm{Na}^{+}$dan $\mathrm{Li}^{+}$sebagai ion structural ordering. Kapabilitas pembentukan pelindung repulsi elektrostatik dari gugus sulfat lebih efektif karena mempengaruhi pembentukan dan agregasi dari helices. Keberadaan ion monovalen dapat memnstabilkan jaringan gel yang kemudian meningkatkan stabilitas jaringan gel ${ }^{(31)}$. Sedangkan untuk kation divalen, yakni $\mathrm{Ba}^{++}>\mathrm{Sr}^{++}>\mathrm{Ca}^{++}>\mathrm{Mg}^{++}$. Efektivitas pengaruh ion terhadap peningkatan gel dan temperatur leleh gel diurutkan mulai dari $\mathrm{K}^{+}>\mathrm{Ca}^{++}>\mathrm{Na}^{+}$. Kation meningkatkan gelasi karagenan melalui stabilisasi dari konformasi helical dengan melindungi muatan gugus sulfat yang diikuti dengan ikatan kordinasi intermolekular (ion-dipol) dengan polisakarida ke dalam agregat ${ }^{(48)}$.

\section{Pemanfaatan Kombinasi Polimer}

Polimer alami telah banyak digunakan dalam bidang farmasi (Tabel 2) ${ }^{(49)}$. Polimer alami lebih disukai dibandingkan dengan polimer sintetik karena bersifat biodegradabel, biokompatibel, tidak toksik, memiliki kapabilitas tinggi untuk mengembang, stabil pada berbagai macam $\mathrm{pH}$, lebih ekonomis, serta mudah diperoleh ${ }^{(8)}$. Polimer alami jenis polisakarida seperti alginat, gum akasia, karangenan, dan pektin telah banyak digunakan dalam formulasi obat, polimer tersebut memiliki struktur yang mampu membentuk ikatan, mudah dimodifikasi, serta memiliki potensi yang besar ${ }^{(49)}$. Polimer alami yang paling banyak digunakan dalam aplikasi formulasi obat maupun biomedis adalah alginat. Alginat dapat dengan mudah dimodifikasi secara kimia maupun fisika melalui tautan silang sehingga terbentuk hidrogel dan meningkatkan sifat fisika kimia serta aktivitas biologi (9). Alginat telah banyak digunakan secara luas untuk formulasi (Tabel 2). Kombinasi alginat dengan gum akasia telah banyak digunakan dalam formulasi mengenkapsulasi bahan aktif yang bertujuan untuk mencegah degradasi (50), meningkatkan stabilas thermal dan kimia (26,51-53), mengurangi toksisitas (54,55), meningkatkan efektivitas zat aktif (55,56), meningkatkan efiesiensi enkapsulasi (8,57), meningkatkan adsorpsi pada mata ${ }^{(58)}$, serta mengontrol pelepasan zat aktif (25,34,57,59). Kombinasi alginat dengan pektin telah banyak digunakan dalam industri makanan, farmasi, kosmetik, dan biomedis dikarenakan interaksinya yang sinergi. Material kombinasi alginat dan pektin dapat berupa film, gel, dan partikel (20). Penggunaan dalam formulasi obat dapat dimanfaatkan untuk mengenkapsulasi bahan aktif yang bertujuan untuk memproteksi dari degradasi ${ }^{(60)}$, mengontrol pelepasan zat aktif, meningkatkan absorpsi air selama swelling (20), meningkatkan sifat mekanik mikrobeads (61), memproteksi dari cairan lambung, serta meningkatkan efisiensi enkapsulasi (62). Kombinasi alginat dengan karagenan telah banyak digunakan dalam formulasi mengenkapsulasi bahan aktif yang bertujuan untuk meningkatkan efektivitas zat aktif ${ }^{(47,63)}$, meningkatkan kekuatan mekanik ${ }^{(19,64)}$, memiliki kapasitas adsorpsi yang baik ${ }^{(64)}$, mengontrol lipid digesti ${ }^{(65)}$, mengontrol pelepasan zat aktif ${ }^{(6,66-73)}$, meningkatkan stabilitas ${ }^{(74-76)}$, meningkatkan stabilitas tekstur ${ }^{(77)}$, meningkatkan efesiensi enkapsulasi ${ }^{(74,78)}$, meningkatkan kekuatan mekanik dan biologis ${ }^{(79,80)}$, serta sebagai pembawa obat tertarget ${ }^{(73)}$. 
Kombinasi algiant dan karagenan sebagai matriks untuk invertase enzim juga bermanfaat untuk mengatasi masalah kebocoran pada enzim dengan meningkatkan kekuatan mekanik dan stabilitas dari bead alginat ${ }^{(76)}$.

Tabel 2 Aplikasi Penggunaan Kombinasi Polimer Terhadap Formulasi Obat

\begin{tabular}{|c|c|c|c|c|c|}
\hline No & $\begin{array}{l}\text { Jenis } \\
\text { Kombinasi } \\
\text { Polimer }\end{array}$ & Obat & Bentuk Sediaan & Kegunaan Polimer & Referensi \\
\hline 1 & $\begin{array}{l}\text { Alginat dan } \\
\text { Gum Akasia }\end{array}$ & Bromelain & Hidrogel topikal & $\begin{array}{l}\text { Meningkatkan absorpsi } \\
\text { air }\end{array}$ & (34) \\
\hline 2 & $\begin{array}{l}\text { Alginat dan } \\
\text { Gum Akasia } \\
\text { dengan } \\
\text { cross-linker } \\
\mathrm{CaCl}_{2}\end{array}$ & $\begin{array}{l}\text { L-Asam } \\
\text { askorbat }\end{array}$ & Mikroenkapsulasi & $\begin{array}{l}\text { Melindungi degradasi } \\
\text { oksidatif thermal }\end{array}$ & (50) \\
\hline 3 & $\begin{array}{l}\text { Alginat dan } \\
\text { pektin dengan } \\
\text { cross-linker } \\
\mathrm{CaCl}_{2}\end{array}$ & Nisin & Mikroenkapsulasi & $\begin{array}{l}\text { Meningkatkan efisiensi } \\
\text { penjerapan, } \\
\text { meningkatkan kestabilan } \\
\text { dan perilisan selama } \\
\text { periode penyimpanan }\end{array}$ & (61) \\
\hline 4 & $\begin{array}{l}\text { Alginat dan } \\
\text { Gum Akasia } \\
\text { dengan } \\
\text { cross-linker } \\
\mathrm{CaCl}_{2}\end{array}$ & $\begin{array}{l}\text { Natrium } \\
\text { diklofenak }\end{array}$ & Beads kering & $\begin{array}{l}\text { Meningkatkan efisiensi } \\
\text { penjerapan, } \\
\text { meningkatkan kestabilan } \\
\text { dan perilisan yang } \\
\text { terkontrol }\end{array}$ & (8) \\
\hline 5 & $\begin{array}{l}\text { Alginat dan } \\
\text { karagenan } \\
\text { dengan } \\
\text { cross-linker } \\
\text { EDTA }\end{array}$ & Anti-mikrobia & Film & $\begin{array}{l}\text { Meningkatkan efek } \\
\text { antimibrobia }\end{array}$ & (47) \\
\hline 6 & $\begin{array}{l}\text { Alginat dan } \\
\text { karagenan } \\
\text { dengan } \\
\text { cross-linker } \\
\mathrm{CaCl}_{2}\end{array}$ & Minyak jagung & Mikrogel & $\begin{array}{l}\text { Mengontrol kecepatan } \\
\text { dan memperpanjang } \\
\text { digesti lipid }\end{array}$ & (65) \\
\hline 7 & $\begin{array}{l}\text { Alginat dan } \\
\text { gum akasia } \\
\text { dan } \\
\text { glutaraldehid }\end{array}$ & Zinc oksida & Nanohidrogel & $\begin{array}{l}\text { Meningkatkan efektifitas } \\
\text { antimikroba }\end{array}$ & (81) \\
\hline 8 & $\begin{array}{l}\text { Alginat dan } \\
\text { graft-karagena } \\
\mathrm{n} \text { termodifikasi } \\
\text { dengan } \\
\text { cross-linker } \\
\mathrm{AlCl}_{3}\end{array}$ & Diltiazem HCl & Hidrogel bead & $\begin{array}{l}\text { Membentuk suatu } \\
\text { pelepasan terkontrol }\end{array}$ & (82) \\
\hline 9 & $\begin{array}{l}\text { Alginat dan } \\
\text { gum akasia } \\
\text { dengan } \\
\text { cross-linker } \\
\mathrm{CaCl}\end{array}$ & Kurkumin & Nanopartikel & $\begin{array}{l}\text { Meningkatkan efek } \\
\text { antioksidan }\end{array}$ & (25) \\
\hline
\end{tabular}




\begin{tabular}{|c|c|c|c|c|c|}
\hline 10 & $\begin{array}{l}\text { Alginat dan } \\
\text { pektin dengan } \\
\text { cross-linker } \\
\mathrm{CaCl}_{2}\end{array}$ & Asam folat & Mikrokapsul & $\begin{array}{l}\text { Meningkatkan stabilitas } \\
\text { asam folat }\end{array}$ & \\
\hline 11 & $\begin{array}{l}\text { Alginat dan } \\
\text { karagenan } \\
\text { dengan } \\
\text { cross-linker } \\
\mathrm{CaCl}_{2}\end{array}$ & Enzim amilase & Mikrosperes & $\begin{array}{l}\text { Meningkatkan stabilitas } \\
\text { enzim } \alpha \text {-amilase }\end{array}$ & (68) \\
\hline 12 & $\begin{array}{l}\text { Alginat dan } \\
\text { karagenan } \\
\text { dengan } \\
\text { cross-linker } \\
\text { glutaraldehid }\end{array}$ & $\begin{array}{l}\text { Kompleks } \\
\text { propanolol } \\
\text { resin }\end{array}$ & Tablet & Pelepasan obat terkontrol & (69) \\
\hline 13 & $\begin{array}{l}\text { Alginat dan } \\
\text { karagenan } \\
\text { dengan } \\
\text { cross-linker } \\
\mathrm{CaCl}_{2}\end{array}$ & Siprofloksasin & Gel absorben & $\begin{array}{l}\text { Meningkatkan sifat } \\
\text { mekanik sebagai } \\
\text { absorben untuk polutan }\end{array}$ & (64) \\
\hline 14 & $\begin{array}{l}\text { Alginat dan } \\
\text { karagenan } \\
\text { dengan } \\
\text { cross-linker } \\
\mathrm{CaCl}_{2}\end{array}$ & Insulin & Insulin oral & $\begin{array}{l}\text { Meningkatkan kestabilan } \\
\text { insulin dalam lingkungan } \\
\text { asam lambung dan } \\
\text { membuat pelepasan } \\
\text { insulin terkontrol dari } \\
\text { intestin }\end{array}$ & (71) \\
\hline 15 & $\begin{array}{l}\text { Alginat dan } \\
\text { gum akasia } \\
\text { dengan } \\
\text { cross-linker } \\
\text { glutaraldehid }\end{array}$ & Zinc oksida & Nanopartikel & $\begin{array}{l}\text { Meningkatkan efikasi zink } \\
\text { oksida sebagai } \\
\text { penyembuhan luka }\end{array}$ & (56) \\
\hline 16 & $\begin{array}{l}\text { Alginat dan } \\
\text { karagenan } \\
\text { dengan } \\
\text { cross-linker } \\
\mathrm{KCl} \text { dan } \\
\mathrm{CaCl} 2\end{array}$ & N/A & N/A & $\begin{array}{l}\text { Sebagai pengenkapsulasi } \\
\text { obat dan sistem } \\
\text { penghantaran obat } \\
\text { terkontrol }\end{array}$ & (72) \\
\hline 17 & $\begin{array}{l}\text { Alginat dan } \\
\text { gum akasia }\end{array}$ & N/A & N/A & $\begin{array}{l}\text { Sebagai material polimer } \\
\text { yang stabil secara } \\
\text { thermal }\end{array}$ & (51) \\
\hline 18 & $\begin{array}{l}\text { Alginat dan } \\
\text { gum akasia } \\
\text { dengan } \\
\text { cross-linker } \\
\mathrm{CaCl}_{2}\end{array}$ & Glibenkamid & Beads kering & Pelepasan obat terkontrol & (57) \\
\hline 19 & $\begin{array}{l}\text { Alginat dan } \\
\text { pektin dengan } \\
\text { cross-linker } \\
\mathrm{CaCl}_{2}\end{array}$ & BSA & Komposit gel & Sebagai penyembuh luka & (20) \\
\hline
\end{tabular}




\begin{tabular}{|c|c|c|c|c|c|}
\hline 20 & $\begin{array}{l}\text { Alginat dan } \\
\text { gum akasia } \\
\text { dengan } \\
\text { cross-linker } \\
\text { glutaraldehid }\end{array}$ & Zinc oksida & Nanopartikel & $\begin{array}{l}\text { Meningkatkan efikasi zink } \\
\text { oksida sebagai } \\
\text { penyembuhan luka dan } \\
\text { mengurangi efek } \\
\text { samping }\end{array}$ & $(55)$ \\
\hline 21 & $\begin{array}{l}\text { Alginat dan } \\
\text { karagenan } \\
\text { ditambah PEG } \\
\text { dan agen } \\
\text { cross-linker } \\
\text { dengan } \\
\text { 3-Aminopropil } \\
\text { triethoxysilane }\end{array}$ & Lidokain & Hidrogel & Pelepasan obat terkontrol & (6) \\
\hline 22 & $\begin{array}{l}\text { Alginat dan } \\
\text { karagenan } \\
\text { ditambah } \\
\mathrm{CaCl}_{2}\end{array}$ & BSA & Beads & Melindungi dari $\mathrm{pH}$ & (66) \\
\hline 23 & $\begin{array}{l}\text { Alginat dan } \\
\text { karagenan } \\
\text { dengan } \\
\text { cross-linker } \\
\mathrm{CuCl}_{2}\end{array}$ & $\begin{array}{l}\text { Enzim } \\
\text { polyphenol } \\
\text { oxidase }\end{array}$ & Beads & $\begin{array}{l}\text { Meningkatkan aktivitas } \\
\text { katekolase }\end{array}$ & (75) \\
\hline 24 & $\begin{array}{l}\text { Alginat dan } \\
\text { karagenan } \\
\text { dengan } \\
\text { cross-linker }\end{array}$ & Logam Ag & $\begin{array}{l}\text { Hidrogel } \\
\text { nanopartikel }\end{array}$ & $\begin{array}{l}\text { Meningkatkan mekanik, } \\
\text { struktul, dan sifat kimia } \\
\text { untuk penyembuh luka } \\
\text { bakar }\end{array}$ & (80) \\
\hline
\end{tabular}

Algingtsleerifat biokompatibel untuk pemberian obat melalui okular, nasal, topikal, lokal, maupun oral. FDA (Food and Drug Administration) telah mengonfirmasi terkait keamanan alginat sebagai komposisi obat untuk pemberian oral. Namun, ada kemungkinan material alginat mengandung komposisi yang bersifat imunogenik, seperti logam berat, endotoksin, protein, dan polifenol. Maka dari itu, pentingnya dekontaminasi pada proses ekstraksi untuk memastikan alginat yang digunakan sudah sangat murni ${ }^{(9)}$.

Polimer alami seperti polisakarida, gum, kitosan, dan alginat dapat membentuk suatu spherical microbeads yang berpotensi sebagai alternatif penghantaran obat menjadi bentuk perilisan terkontrol ${ }^{(83,84)}$. Tujuan dari pelepasan terkontrol adalah untuk menjaga konsentrasi obat pada level yang tetap dalam periode waktu tertentu, untuk menurunkan frekuensi pemberian dosis, meningkatkan level keamanan dari obat, meningkatkan tingkat kepatuhan pasien, menurunkan fluktuasi, menurunkan efek samping lokal dan sistemik ${ }^{(85)}$, serta memperlama durasi aksi obat, dan memastikan respon farmakokinetik dan farmakodinamik dapat reprodusibel dan diprediksi. Selain itu, polimer dapat pula dimodifikasi sedemikian rupa untuk menjadi sistem penghantaran obat tertarget pada organ tertentu ${ }^{(83)}$. 
Polimer alami yang memiliki gugus hidroksil bersifat mukoadesif. Gugus hidroksil dari polimer hidrofilik dapat menempel pada membran mukus yang berasal dari berbagai interaksi, seperti ikatan hidrogen, van der Waal's, interaksi ionik, dan pembentukan matriks jaringan polimer. Daya tarik elektrostatik yang kuat akan berkontribusi terbentukna suatu mukoadesi yang baik antara mucin dan polimer ${ }^{(86)}$. Alginat merupakan polimer mukoadesif larut air yang memiliki struktur berupa polisakarida linear berupa asam guluronat dan asam manuronat yang dapat membentuk ikatan hidrogen kuat dengan glikoprotein musin mucosal dari interaksi gugus karboksil dan hidroksil ( ${ }^{87)}$. Alginat dapat meningkatkan permeasi obat termasuk protein seperti insulin melewati mukosa intestinal dengan cara meningkatkan kemampuan absorpsinya serta mampu menghantarkan insulin melalui oral karena dapat melindungi obat dari degradasi enzim gastrointestinal ${ }^{(88)}$.

Polimer alami telah banyak digunakan sebagai agen penyembuh luka, khususnya alginat. Hal ini dikarenakan sifat alginat yang biokompatibel, biodegradable, dan kemiripan dengan matriks ekstraselular tubuh yang membantu dalam proses penyembuhan luka ${ }^{(89)}$. Alginat berpotensi sebagai material agen penyembuh luka karena mengandung tinggi air, elastik, permeable, kemampuan untuk membentuk lingkungan yang lembab, terlarut dalam $\mathrm{pH}$ yang lebih tinggi dibandingkan dengan medium asam, hal ini sejalan dengan $\mathrm{pH}$ lingkungan luka antara 7.15-8.9 ${ }^{(90)}$. Alginat dapat membantu memicu re-epitelisasi dan mengurangi pembentukan scar (91), meningkatkan aktivitas makrofag dan level sitokin (92), memiliki kemampuan anti-inflamasi, dan melepaskan obat secara terkontrol untuk menyembuhkan luka (89). Penambahan agen cross-linker seperti kalsium ke dalam pembuatan alginat juga memberikan manfaat farmakologis, yakni kemampuan hemostatis yang dapat mengagregasi plate dan eritrosit sehingga bermanfaat terhadap penyembuhaan luka (91). Kombinasi alginat dengan pektin dapat mempercepat pengelupasan eksudat luka dengan membentuk gel lembut diatas luka, membentuk barier bakteri atau virus melalui retensi keasaman atmosfer, dan juga melindungi faktor pertumbuhan dari degradasi ${ }^{(92)}$.

Alginat telah banyak digunakan dalam modifikasi penghantaran obat, termasuk sebagai penghantaran obat tertarget pada kolon karena dapat termetabolisme oleh enzim glukosidase di kolon ${ }^{(93,94)}$. Alginat memperlihatkan efek perilisan terkontrol dan tertarget pada sekum (bagian dari usus besar), khususnya untuk natrium alginat viskositas rendah ${ }^{(95)}$. Alginat mudah mengembang dan terdisintegrasi di usus halus karena pada $\mathrm{pH}$ gastrointestinal yang lebih tinggi seperti suasana pada usus, matriks alginat akan berubah menjadi lapisan viscous larut yang merusak integritas polimer dan melepaskan obat dari mikrokapsul. Hal ini dapat meningkatkan porositas dan solubilisasi polimer ${ }^{(95)}$. Kombinasi alginat dan pektin juga telah digunakan dalam formulasi obat penghantaran tertarget pada kolon. Namun, diperlukan tambahan polimer agar tidak terjadi pelepasan yang terlalu cepat di usus ${ }^{(94)}$. 


\section{Kesimpulan}

Sinergisitas merupakan parameter untuk mengetahui apakah kombinasi polimer dapat memberikan efek yang lebih menguntungkan ketika dikombinasi. Interaksi yang saling menguntungkan antar polimer dapat dilihat dari nilai sinergisitas viskositas. Dikatakan adanya efek sinergi jika sistem dispersi memiliki viskositas lebih tinggi pada kombinasi lebih dari satu hidrokolid polimer dibandingkan dengan hidrokoloid tunggal. Efek sinergi dapat ditingkatkan dengan menambahkan suatu agen cross-linker seperti ion logam $\mathrm{Ca}^{2+}$. Pada polimer seperti alginat, pektin, dan karagenan, dapat membentuk interaksi dengan ion logam $\mathrm{Ca}^{2+}$. Kombinasi polimer telah banyak digunakan dalam formulasi obat, terutama penggunaan alginat yang dikombinasi dengan polimer alami lainnya. Tujuan penggunaannya dalam formulasi obat antara lain untuk mencegah degradasi, meningkatkan stabilas thermal dan kimia, mengurangi toksisitas, meningkatkan efektivitas zat aktif, meningkatkan efiesiensi enkapsulasi, meningkatkan adsorpsi pada mata, mengontrol pelepasan zat aktif, maupun sebagai pembawa obat tertarget. Formulasi dengan polimer menghasilkan obat dengan pelepasan terkontrol, yang memiliki keuntungan, yakni dapat menurunkan frekuensi pemberian dosis, menurunkan efek samping obat, meningkatkan tingkat kepatuhan pasien, menurunkan fluktuasi, serta memperlama durasi aksi obat, dan memastikan respon farmakokinetik dan farmakodinamik dapat reprodusibel dan diprediksi. Selain itu, polimer dapat pula dimodifikasi sedemikian rupa untuk menjadi sistem penghantaran obat tertarget pada organ tertentu.

\section{Ucapan Terima Kasih}

Penulis mengucapkan terima kasih kepada Kementerian Pendidikan, Kebudayaan, Riset dan Teknologi yang telah memberikan beasiswa PMDSU sehingga penulis termotivasi untuk menulis artikel ini.

\section{Daftar Pustaka}

1. Gohil RM. Synergistic Blends of Natural Polymers, Pectin, and Sodium Alginate. Journal of Applied Polymer Science, 2010; 120(2011):2324-2336.

2. Walkenström P, Kidman S, Hermansson AM, Rasmussen PB, Hoegh L. Microstructure and rheological behaviour of alginate/pectin mixed gels. Food Hydrocolloids, 2003; 17(5):593-603.

3. Cheng T, Xu J, Li Y, Zhao Y, Bai Y, Fu X, Gao X, Mao X. Effect of gum ghatti on physicochemical and microstructural properties of biodegradable sodium alginate edible films. Journal of Food Measurement and Characterization, 2020; (0123456789).

4. Cengiz E, Dogan M, Karaman S. Characterization of rheological interactions of Gleditsia triacanthos gum with some hydrocolloids: Effect of hydration temperature. Food Hydrocolloids, 2013; 32(2):453-462.

5. Ahmad S, Ahmad M, Manzoor K, Purwar R, Ikram S. A review on latest innovations in natural gums based hydrogels: Preparations \& applications. International Journal of Biological Macromolecules, 2019; 136:870-890. 
6. Rasool A, Ata S, Islam A, Rizwan M, Azeem MK, Mehmood A, Khan RU, Qureshi A ur R, Mahmood HA. Kinetics and controlled release of lidocaine from novel carrageenan and alginate-based blend hydrogels. International Journal of Biological Macromolecules, 2020; 147:67-78.

7. Pal K, Banerjee I, Sarkar P, Kim D, Deng W-P, Dubey NK, Majumder K. Biopolymer-Based Formulations : Biomedical and Food Applications., 2020.

8. Benfattoum K, Haddadine N, Bouslah N, Benaboura A, Maincent P, Barillé R, Sapin-Minet A, El-Shall MS. Formulation characterization and in vitro evaluation of acacia gum-calcium alginate beads for oral drug delivery systems. Polymers for Advanced Technologies, 2018; 29(2):884-895.

9. Plavšić $M$, Strmečki S. Carbohydrate polymers as constituents of exopolymer substances in seawater, their complexing properties towards copper ions, surface and catalytic activity determined by electrochemical methods. Carbohydrate Polymers, 2016; 135:48-56.

10. Nkenmogne Kamdem IE, Saidou C, Ngassoum MB, Ndjouenkeu R. Synergistic interactions in dilute aqueous solutions between alginate and tropical vegetal hydrocolloids. Heliyon, 2020; 6(7).

11. Marimuthu M, llansuriyan $P$, Yap TN, Shanmugam M. Interaction of semi-refined carrageenan (E407A) with nano quanta of some food hydrocolloids and their physiochemical, functional and rheological properties. Journal of Microbiology, Biotechnology and Food Sciences, 2017; 6(4):1049-1053.

12. Menchicchi B, Fuenzalida JP, Hensel A, Swamy MJ, David L, Rochas C, Goycoolea FM. Biophysical Analysis of the Molecular Interactions between Polysaccharides and Mucin. Biomacromolecules, 2015; 16(3):924-935.

13. Rao MA. Rheology of Food Gum and Starch Dispersions. 1980; (1986).

14. Busch VM, Delgado JF, Santagapita PR, Wagner JR, Buera MP. Rheological characterization of vinal gum, a galactomannan extracted from Prosopis ruscifolia seeds. Food Hydrocolloids, 2018; 74:333-341.

15. Singh V, Preeti, Singh A, Singh D, Singh Y, Pandey AK. Synthesis and characterization of guar-alginate hybrid bead templated mercury sorbing titania spheres. International Journal of Biological Macromolecules, 2015; 72:261-268.

16. Karasu S, Doğan M, Toker ÖS, Caniyilmaz E. Modeling of rheological properties of mellorine mix including different oil and gum types by combined design, ANN, and ANFIS models. Turkish Journal of Agriculture and Forestry, 2014; 38(5):745-757.

17. Liang S, Li B, Ding Y, Xu BL, Chen J, Zhu B, Ma MH, Kennedy JF, Knill CJ. Comparative investigation of the molecular interactions in konjac gum/hydrocolloid blends: Concentration addition method (CAM) versus viscosity addition method (VAM). Carbohydrate Polymers, 2011; 83(3):1062-1067

18. Pérez-Mateos M, Hurtado JL, Montero $P$, Fernández-Martín F. Interactions of $\mathrm{K}$-carrageenan plus other hydrocolloids in fish myosystem gels. Journal of Food Science, 2001; 66(6):838-843.

19. Ye Z, Ma P, Tang M, Li X, Zhang W, Hong X, Chen X, Chen D. Interactions between calcium alginate and carrageenan enhanced mechanical property of a natural composite film for general packaging application. Polymer Bulletin, 2017; 74(8):3421-3429. 
20. Oh GW, Nam SY, Heo SJ, Kang DH, Jung WK. Characterization of ionic cross-linked composite foams with different blend ratios of alginate/pectin on the synergistic effects for wound dressing application. International Journal of Biological Macromolecules, 2020; 156:1565-1573.

21. Bekhit M, Sánchez-González L, Ben Messaoud G, Desobry S. Design of microcapsules containing Lactococcus lactis subsp. lactis in alginate shell and xanthan gum with nutrients core. LWT - Food Science and Technology, 2016; 68:446-453.

22. Pongjanyakul T, Puttipipatkhachorn S. Xanthan-alginate composite gel beads: Molecular interaction and in vitro characterization. International Journal of Pharmaceutics, 2007; 331(1):61-71.

23. Higiro J, Herald TJ, Alavi S. Rheological study of xanthan and locust bean gum interaction in dilute solution. Food Research International, 2006; 39(2):165-175.

24. Yamazaki E, Kurita O, Matsumura Y. Hydrocolloid from leaves of Carchorus olitorius and its synergistic effect on k-carrageenan gel strength. Food Hydrocolloids, 2007; 22(2008):819-825.

25. Hassani A, Mahmood S, Enezei HH, Hussain SA, Hamad HA, Aldoghachi AF, Hagar A, Doolaanea AA, Ibrahim WN. Formulation, characterization and biological activity screening of sodium alginate-gum Arabic nanoparticles loaded with curcumin. Molecules, 2020; 25(9).

26. Tsai $\mathrm{F}-\mathrm{H}$, Kitamura $\mathrm{Y}$, Kokawa $\mathrm{M}$. Effect of gum arabic-modified alginate on physicochemical properties, release kinetics, and storage stability of liquid-core hydrogel beads. Carbohydrate Polymers, 2017; 174:1069-1077.

27. Chanamai R, McClements DJ. Comparison of gum arabic, modified starch, and whey protein isolate as emulsifiers: Influence of $\mathrm{pH}, \mathrm{CaCl} 2$ and temperature. Journal of Food Science, 2002; 67(1):120-125.

28. Cao L, Lu W, Mata A, Nishinari K, Fang Y. Egg-box model-based gelation of alginate and pectin: A review. Carbohydrate Polymers, 2020; 242(April):116389.

29. Sworn G. Handbook of Hydrocolloids. Cambridge: Woodhead Publishing, 2000.

30. Kim MH, Lee YW, Jung W-K, Oh J, Nam SY. Enhanced rheological behaviors of alginate hydrogels with carrageenan for extrusion-based bioprinting. Journal of the Mechanical Behavior of Biomedical Materials, 2019; 98:187-194.

31. Liu S, Li L. Thermoreversible gelation and scaling behavior of Ca2+-induced K-carrageenan hydrogels. Food Hydrocolloids, 2016; 61:793-800.

32. Morris ER. Mixed Polymer Gels. Pp. 291-359 in Peter Harris (ed). Food Gels. London: Elsevier Applied Science, 1990.

33. Mesakuni T, Atsushi A, Sanehisa N. Rheological aspects of the intermolecular interaction between xanthan and locust bean gum in aqueous media. Agricultural and Biological Chemistry, 1984; 48(12):2995-3000.

34. Ataide J, Cefali L, Rebelo M, Spir L, Tambourgi E, Jozala A, Chaud M, Silveira E, Gu X, Gava Mazzola P. Bromelain Loading and Release from a Hydrogel Formulated Using Alginate and Arabic Gum. Planta Medica, 2017; 83(10):870-876.

35. Spadari C de C, Lopes LB, Ishida K. Potential use of alginate-based carriers as antifungal delivery system. Frontiers in Microbiology, 2017; 8(JAN). 
36. Ching SH, Bansal N, Bhandari B. Alginate gel particles-A review of production techniques and physical properties. Critical Reviews in Food Science and Nutrition, 2017; 57(6):1133-1152.

37. Belitz H., Grosch W, Schieberle P. Food Chemistry. 3rd ed. Jerman: Springer Verlag Berlin Heidelberg, 2004.

38. Li L, Yu F, Zheng L, Wang R, Yan W, Wang Z, Xu J, Wu J, Shi D, Zhu L, Wang X, Jiang Q. Natural hydrogels for cartilage regeneration: Modification, preparation and application. Journal of Orthopaedic Translation, 2019; 17(2):26-41.

39. Martau GA, Mihai M, Vodnar DC. The use of chitosan, alginate, and pectin in the biomedical and food sector-biocompatibility, bioadhesiveness, and biodegradability. Polymers, 2019; 11(11).

40. Nahar K, Hossain MK, Khan TA. Alginate and its versatile application in drug delivery. Journal of Pharmaceutical Sciences and Research, 2017; 9(5):606-617.

41. Raj S. A Review on Pectin: Chemistry due to General Properties of Pectin and its Pharmaceutical Uses. 2012; 1(12):10-13.

42. MacArtain P, Jacquier JC, Dawson KA. Physical characteristics of calcium induced K- carrageenan networks. Carbohydrate Polymers, 2003; 53(4):395-400.

43. Wurm F, Pham T, Bechtold T. Modelling of phase separation of alginate-carrageenan gels based on rheology. Food Hydrocolloids, 2019; 89:765-772.

44. Kara S, Arda E, Pekcan Ö. Monovalent and divalent cation effects on phase transitions of I-carrageenan. Journal of Bioactive and Compatible Polymers, 2007; 22(1):42-61.

45. Tari Ö, Pekcan Ö. Comparison of cation effects on phase transitions of kappa and iota carrageenan. E-Polymers, 2010; (083):1-13.

46. Fan L, Peng K, Li M, Wang L, Wang T. Preparation and properties of carboxymethyl K-carrageenan/alginate blend fibers. Journal of Biomaterials Science, Polymer Edition, 2013; 24(9):1099-1111.

47. Cha DS, Choi JH, Chinnan MS, Park HJ. Antimicrobial films based on Na-alginate and K-carrageenan. LWT - Food Science and Technology, 2002; 35(8):715-719.

48. Lai VMF, Wong PAL, Lii CY. Effects of cation properties on sol-gel transition and gel properties of K-carrageenan. Journal of Food Science, 2000; 65(8):1332-1337.

49. Kulkarni V, Butte K, Rathod S. Natural Polymers - A Comprehensive Review. International Journal of Research in Pharmaceutical and Biomedical Sciences, 2012; 3(4):1597-1613.

50. Barra PA, Márquez K, Gil-Castell O, Mujica J, Ribes-Greus A, Faccini M. Spray-drying performance and thermal stability of L-ascorbic acid microencapsulated with sodium alginate and gum Arabic. Molecules, 2019; 24(16).

51. Nair RM, Bindhu B, V L R. A polymer blend from Gum Arabic and Sodium Alginate preparation and characterization. Journal of Polymer Research, 2020; 27(6).

52. Fagury HS, Talib MA, Rayis OA, El-Hag KH. Extending Cloud Stability of Tamarindus indica L. Juice Using Sodium Alginate and Gum Arabic During Storage in the Refrigerator. Pp. 173-180 in Gum Arabic. Elsevier, 2018.

53. Li J, Zhai J, Dyett B, Yang Y, Drummond CJ, Conn CE. Effect of gum arabic or sodium alginate incorporation on the physicochemical and curcumin retention properties of liposomes. Lwt, 2020:110571. 
54. Chopra M, Bernela M, Kaur P, Manuja A, Kumar B, Thakur R. Alginate/gum acacia bipolymeric nanohydrogels-Promising carrier for Zinc oxide nanoparticles. International Journal of Biological Macromolecules, 2015; 72:827-833.

55. Raguvaran R, Manuja BK, Chopra M, Thakur R, Anand T, Kalia A, Manuja A. Sodium alginate and gum acacia hydrogels of $\mathrm{ZnO}$ nanoparticles show wound healing effect on fibroblast cells. International Journal of Biological Macromolecules, 2017; 96:185-191.

56. Manuja A, Raguvaran R, Kumar B, Kalia A, Tripathi BN. Accelerated healing of full thickness excised skin wound in rabbits using single application of alginate/acacia based nanocomposites of $\mathrm{ZnO}$ nanoparticles. International Journal of Biological Macromolecules, 2020; 155:823-833.

57. Nayak AK, Das B, Maji R. Calcium alginate/gum arabic beads containing glibenclamide: Development and in vitro characterization. International Journal of Biological Macromolecules, 2012; 51(5):1070-1078.

58. Singh V, Preeti. Mesoporous titania spheres derived from sodium alginate-gum acacia composite beads: Efficient adsorbent for "Reactive blue H5G" dye. Journal of Environmental Chemical Engineering, 2015; 3(4):2727-2737.

59. Li M, Li H, Li X, Zhu H, Xu Z, Liu L, Ma J, Zhang M. A Bioinspired Alginate-Gum Arabic Hydrogel with Micro-/Nanoscale Structures for Controlled Drug Release in Chronic Wound Healing. ACS Applied Materials and Interfaces, 2017; 9(27):22160-22175.

60. Guo J, Giusti MM, Kaletunç G. Encapsulation of purple corn and blueberry extracts in alginate-pectin hydrogel particles: Impact of processing and storage parameters on encapsulation efficiency. Food Research International, 2018; 107:414-422.

61. Bekhit M, Sánchez-González L, Ben Messaoud G, Desobry S. Encapsulation of Lactococcus lactis subsp. lactis on alginate/pectin composite microbeads: Effect of matrix composition on bacterial survival and nisin release. Journal of Food Engineering, 2016; 180:1-9.

62. Kiaei Pour P, Alemzadeh I, Vaziri AS, Beiroti A. Potential effects of alginate-pectin biocomposite on the release of folic acid and their physicochemical characteristics. Journal of Food Science and Technology, 2020; 57(9):3363-3370.

63. Tudorache M, Gheorghe A, Negoi A, Enache M, Maria G-M, Parvulescu VI. Bifunctional carbohydrate biopolymers entrapped lipase as catalyst for the two consecutive conversions of a-pinene to oxy-derivatives. Carbohydrate Polymers, 2016; 152:726-733.

64. Li L, Zhao J, Sun Y, Yu F, Ma J. Ionically cross-linked sodium alginate/k-carrageenan double-network gel beads with low-swelling, enhanced mechanical properties, and excellent adsorption performance. Chemical Engineering Journal, 2019; 372:1091-1103.

65. Chen F, Deng Z, Zhang Z, Zhang R, Xu Q, Fan G, Luo T, McClements DJ. Controlling lipid digestion profiles using mixtures of different types of microgel: Alginate beads and carrageenan beads. Journal of Food Engineering, 2018; 238:156-163.

66. Sarıyer S, Duranoğlu D, Doğan Ö, Küçük İ. pH-responsive double network alginate/kappa-carrageenan hydrogel beads for controlled protein release: Effect of $\mathrm{pH}$ and crosslinking agent. Journal of Drug Delivery Science and Technology, 2020; 56(January). 
67. Giri TK, Verma D, Badwaik HR. Effect of aluminium chloride concentration on diltiazem hydrochloride release from $\mathrm{pH}$-sensitive hydrogel beads composed of hydrolyzed grafted k-carrageenan and sodium alginate. Current Chemical Biology, 2017; 11(1):44-49.

68. Kolesnyk I, Konovalova V, Burban A. Alginate/K-Carrageenan Microspheres and their Application for Protein Drugs Controlled Release. Chemistry \& Chemical Technology, 2015; 9(4):485-492.

69. Kulkarni R V., Baraskar V V., Mallikarjun Setty C, Sa B. Interpenetrating polymer network matrices of sodium alginate and carrageenan for controlled drug delivery application. Fibers and Polymers, 2011; 12(3):352-358.

70. Wang $\mathrm{Y}$, Liu M, Ni B, Xie L. K-Carrageenan-sodium alginate beads and superabsorbent coated nitrogen fertilizer with slow-release, water-retention, and anticompaction properties. Industrial and Engineering Chemistry Research, 2012; 51(3):1413-1422.

71. Lim H-P, Ooi C-W, Tey B-T, Chan E-S. Controlled delivery of oral insulin aspart using $\mathrm{pH}$-responsive alginate/K-carrageenan composite hydrogel beads. Reactive and Functional Polymers, 2017; 120:20-29.

72. Mohamadnia Z, Zohuriaan-Mehr MJ, Kabiri K, Jamshidi A, Mobedi H. Ionically cross-linked carrageenan-alginate hydrogel beads. Journal of Biomaterials Science, Polymer Edition, 2008; 19(1):47-59.

73. Ana Belščak-Cvitanovic' a, $\Uparrow$, Draženka Komes a, Sven Karlovic' a SD a, Igor Špoljaric' b, Gordan Mršic' b DJ. Improving the controlled delivery formulations of caffeine in alginate hydrogel beads combined with pectin, carrageenan, chitosan and psyllium. Food chem, 2015; 167(2015):378-386.

74. Abdelghany S, Alkhawaldeh M, AlKhatib HS. Carrageenan-stabilized chitosan alginate nanoparticles loaded with ethionamide for the treatment of tuberculosis. Journal of Drug Delivery Science and Technology, 2017; 39:442-449.

75. Yagar H, Kocaturk S. Comparison of some biochemical properties of artichoke polyphenol oxidase entrapped in alginate-carrageenan and alginate gels. Artificial Cells, Nanomedicine and Biotechnology, 2014; 42(4):268-273.

76. Malhotra I, Basir SF. Immobilization of invertase in calcium alginate and calcium alginate-kappa-carrageenan beads and its application in bioethanol production. Preparative Biochemistry \& Biotechnology, 2020; 50(5):494-503.

77. Farhah AN, Ekantari N. Combination of Sodium Alginate and Kappa-Carrageenan Increases Texture Stability of Spirulina platensis Ice Cream. P. in E3S Web of Conferences. Vol 147. 2020.

78. Güven KC, Yurdun T, Aksoy A. The clarification and retention of zinc and manganese from raw water by alginate and carrageenan. Acta Pharmaceutica Sciencia, 2006; 48(2):129-139.

79. Ki SB, Singh D, Kim SC, Son TW, Han SS. Effect of cross-linkers in fabrication of carrageenan-alginate matrices for tissue engineering application. Biotechnology and Applied Biochemistry, 2013; 60(6):589-595.

80. Zia T, Usman M, Sabir A, Shafiq M, Khan RU. Development of inter-polymeric complex of anionic polysaccharides, alginate/k-carrageenan bio-platform for burn dressing. International Journal of Biological Macromolecules, 2020; 157:83-95. 
81. Chopra M, Bernela M, Kaur P, Manuja A, Kumar B, Thakur R. Alginate/gum acacia bipolymeric nanohydrogels-Promising carrier for Zinc oxide nanoparticles. International Journal of Biological Macromolecules, 2015; 72:827-833.

82. Giri TK, Verma D, Badwaik HR. Effect of Aluminium Chloride Concentration on Diltiazem Hydrochloride Release from pH-sensitive Hydrogel Beads Composed of Hydrolyzed Grafted k-Carrageenan and Sodium Alginate. Current Chemical Biology, 2017; 11(1):44-49.

83. Ghosal K, Adak S, Agatemor C, G P, Kalarikkal N, Thomas S. Novel interpenetrating polymeric network based microbeads for delivery of poorly water soluble drug. Journal of Polymer Research, 2020; 27(4).

84. Kulkarni AR, Soppimath KS, Aminabhavi TM, Rudzinski WE. In-vitro release kinetics of cefadroxil-loaded sodium alginate interpenetrating network beads. European Journal of Pharmaceutics and Biopharmaceutics, 2001; 51(2):127-133.

85. Mandhar P, Joshi G. Development of Sustained Release Drug Delivery System: A Review. Asian Pacific Journal of Health Sciences, 2015; 2(1):179-185.

86. Azad AK, Doolaanea AA, Al-Mahmood SMA, Kennedy JF, Chatterjee B, Bera H. Electro-hydrodynamic assisted synthesis of lecithin-stabilized peppermint oil-loaded alginate microbeads for intestinal drug delivery. International Journal of Biological Macromolecules, 2021; 185:861-875.

87. Al-Joufi F, Elmowafy M, Alruwaili NK, Alharbi KS, Shalaby K, Alsharari SD, Ali HM. Mucoadhesive in situ rectal gel loaded with rifampicin: Strategy to improve bioavailability and alleviate liver toxicity. Pharmaceutics, 2021; 13(3):1-17.

88. Koland M, Anchan RB, Mukund SG, Mulleria SS. Design and investigation of alginate coated solid nanoparticles for oral insulin delivery. Indian Journal of Pharmaceutical Education and Research, 2021; 55(2):283-294.

89. Summa M, Russo D, Penna I, Margaroli N, Bayer IS, Bandiera T, Athanassiou A, Bertorelli R. A biocompatible sodium alginate/povidone iodine film enhances wound healing. European Journal of Pharmaceutics and Biopharmaceutics, 2018; 122:17-24.

90. Sarheed O, Abdul Rasool BK, Abu-Gharbieh E, Aziz US. An Investigation and Characterization on Alginate Hydogel Dressing Loaded with Metronidazole Prepared by Combined Inotropic Gelation and Freeze-Thawing Cycles for Controlled Release. AAPS PharmSciTech, 2015; 16(3):601-609.

91. Yu W, Jiang YY, Sun TW, Qi C, Zhao H, Chen F, Shi Z, Zhu YJ, Chen D, He Y. Design of a novel wound dressing consisting of alginate hydrogel and simvastatin-incorporated mesoporous hydroxyapatite microspheres for cutaneous wound healing. RSC Advances, 2016; 6(106):104375-104387.

92. Rezvanian M, Ng SF, Alavi T, Ahmad W. In-vivo evaluation of Alginate-Pectin hydrogel film loaded with Simvastatin for diabetic wound healing in Streptozotocin-induced diabetic rats. International Journal of Biological Macromolecules, 2021; 171:308-319.

93. Wang Y, Li Y, He L, Mao B, Chen S, Martinez V, Guo X, Shen X, Liu B, Li C. Commensal flora triggered target anti-inflammation of alginate-curcumin micelle for ulcerative colitis treatment. Colloids and Surfaces B: Biointerfaces, 2021; 203(April):111756. 
94. Zhao QQ, Zhang XY, Tang XF, Qiao H. A novel and oral colon targeted isoliquiritigenin delivery system: Development, optimization, characterization and in vitro evaluation. Journal of Drug Delivery Science and Technology, 2021; 66(199):102777.

95. Wagle SR, Kovacevic B, lonescu CM, Walker D, Jones M, Carey L, Takechi R, Mikov M, Mooranian A, Al-Salami H. Pharmacological and biological study of microencapsulated probucol-secondary bile acid in a diseased mouse model. Pharmaceutics, 2021; 13(8). 